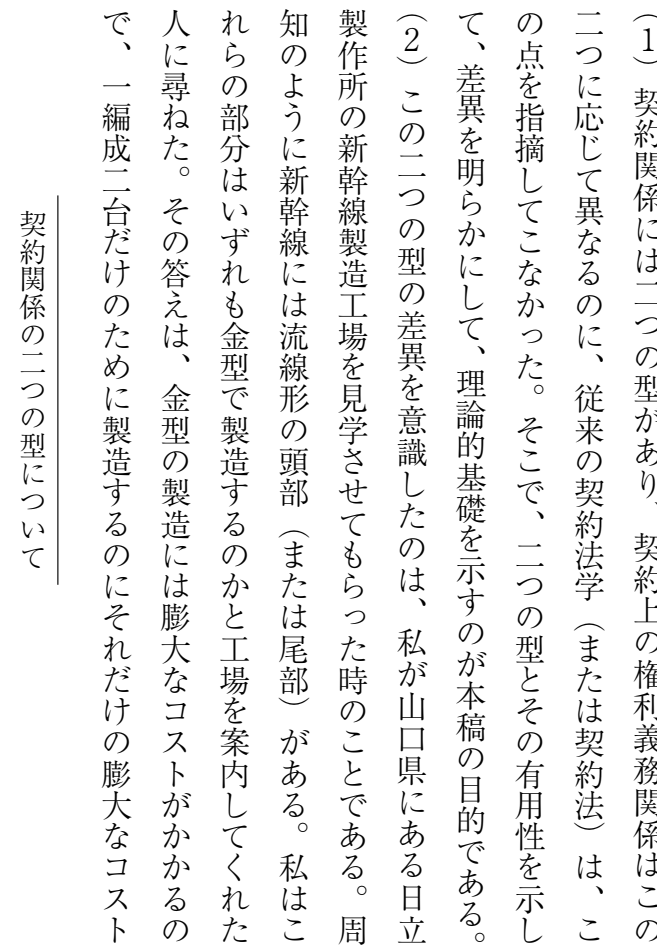

は
よ
に

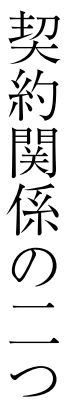

の

型

に

ᄂ)

履に取らる。約大取 3 不私ちを

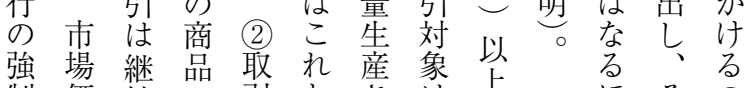

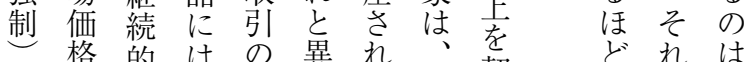

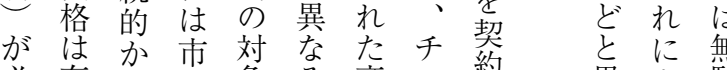

必存つ場象る商当絓思よ駅

要在複価は。品コ学染う然

と雑格市そ㤎し学たてあ

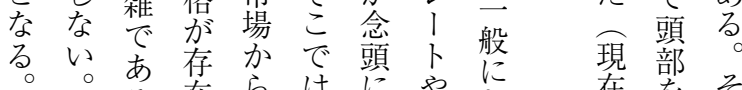

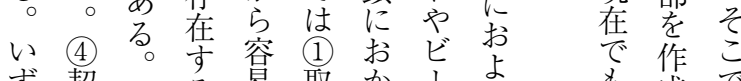

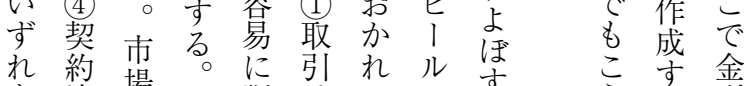

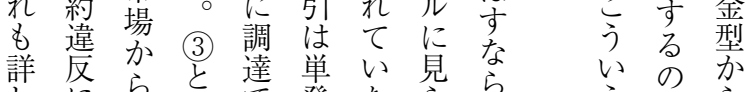

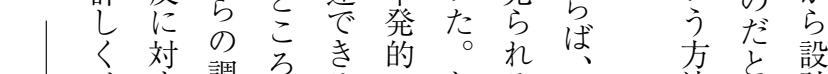

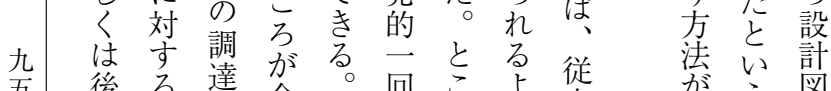

五、後方達金し回等

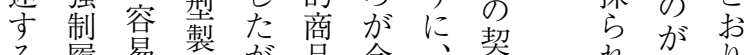

る履易製が品金、絜秋答り

な契て

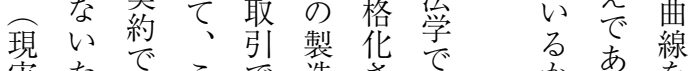

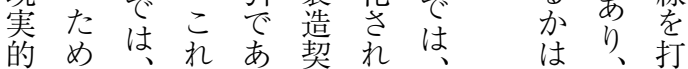

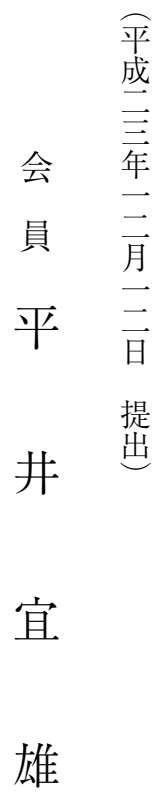




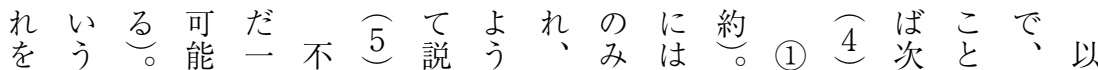

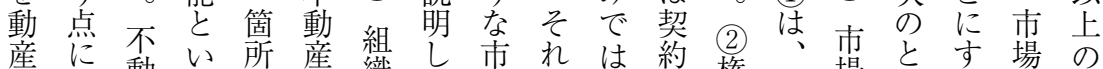

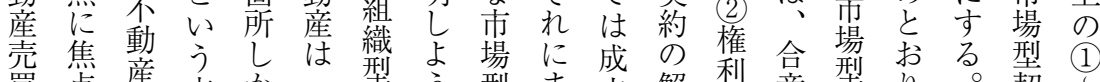

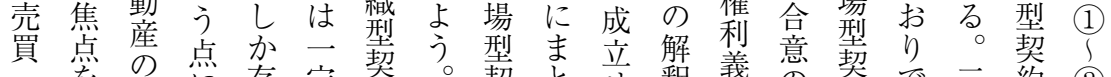

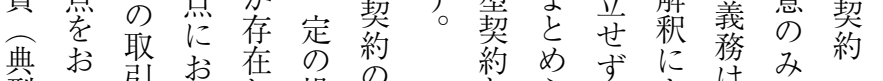

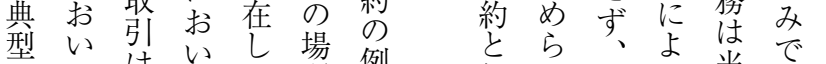
はて はてな所例縕れ㛃う当成

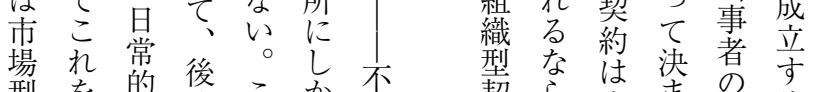

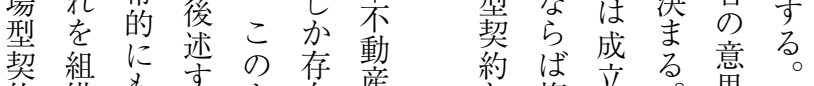

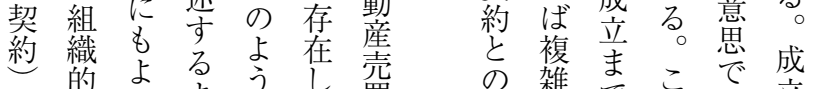

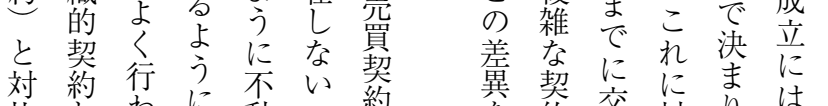

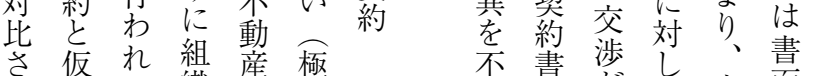

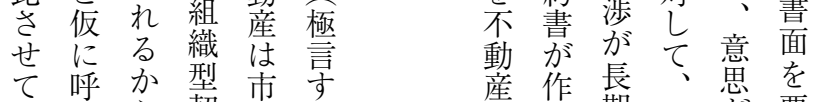
説忍ら契場れ 明こ調約かば よに挃類の地 う方不似調 球 \begin{tabular}{llll} 
る & 可 & 達 & 上 \\
こ & 能 & が & 不 \\
\hline & と &
\end{tabular} 産作長、惫を

嘪さと織 明し 契れわ型確な 約るた契でい を以例以て約な舞 に上行拿場成

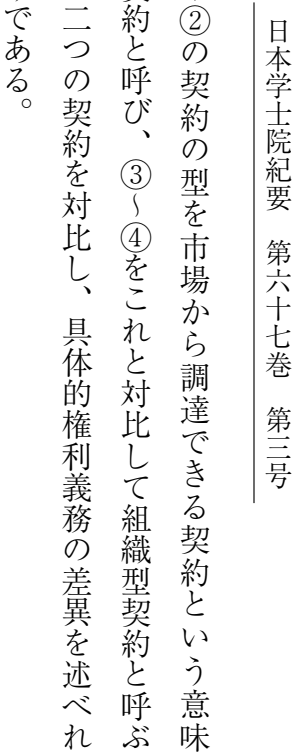

$\begin{array}{lll}\text { ほ } & \text { ら } \\ \text { と } & \text { 調 } & \text { 不 }\end{array}$

んべ動こ質成う る 壳 由 立 1 どな産ろる 諾約い、契どは諾

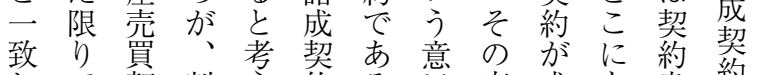
て

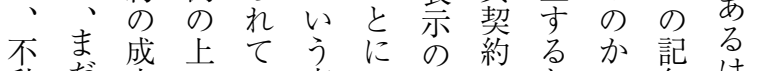

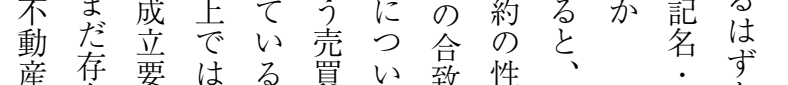

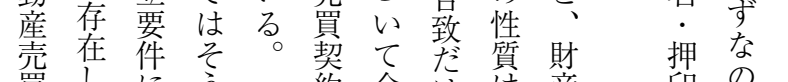

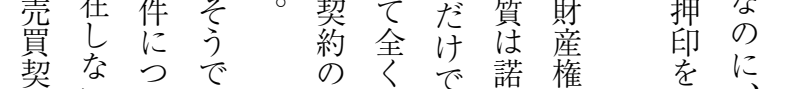
約よして 立 で文。京 抱 る

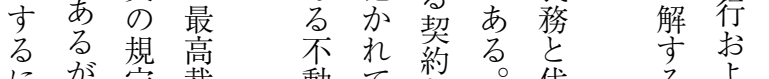
にが定裁 動て

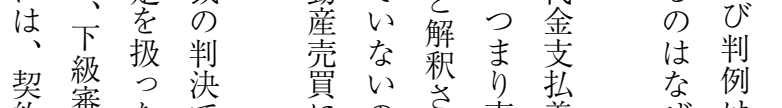

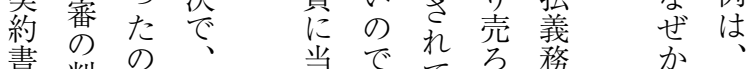
書判は正当然て う務方势

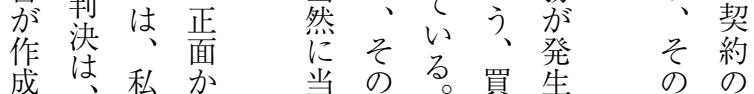

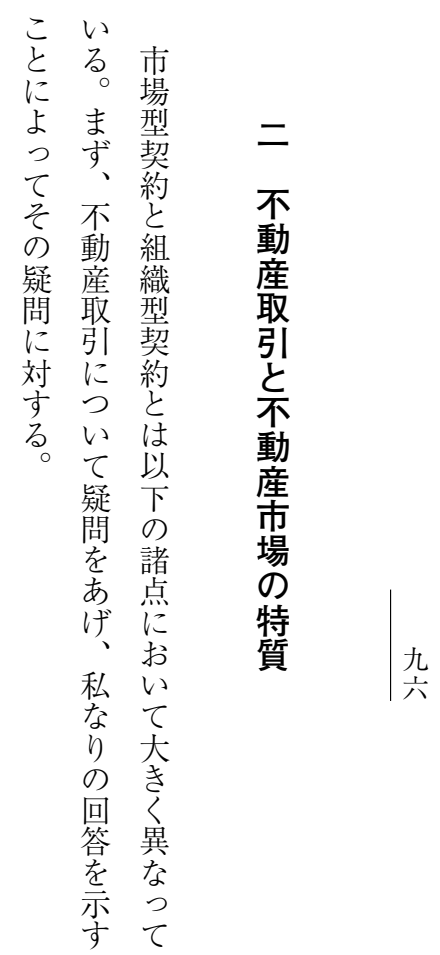




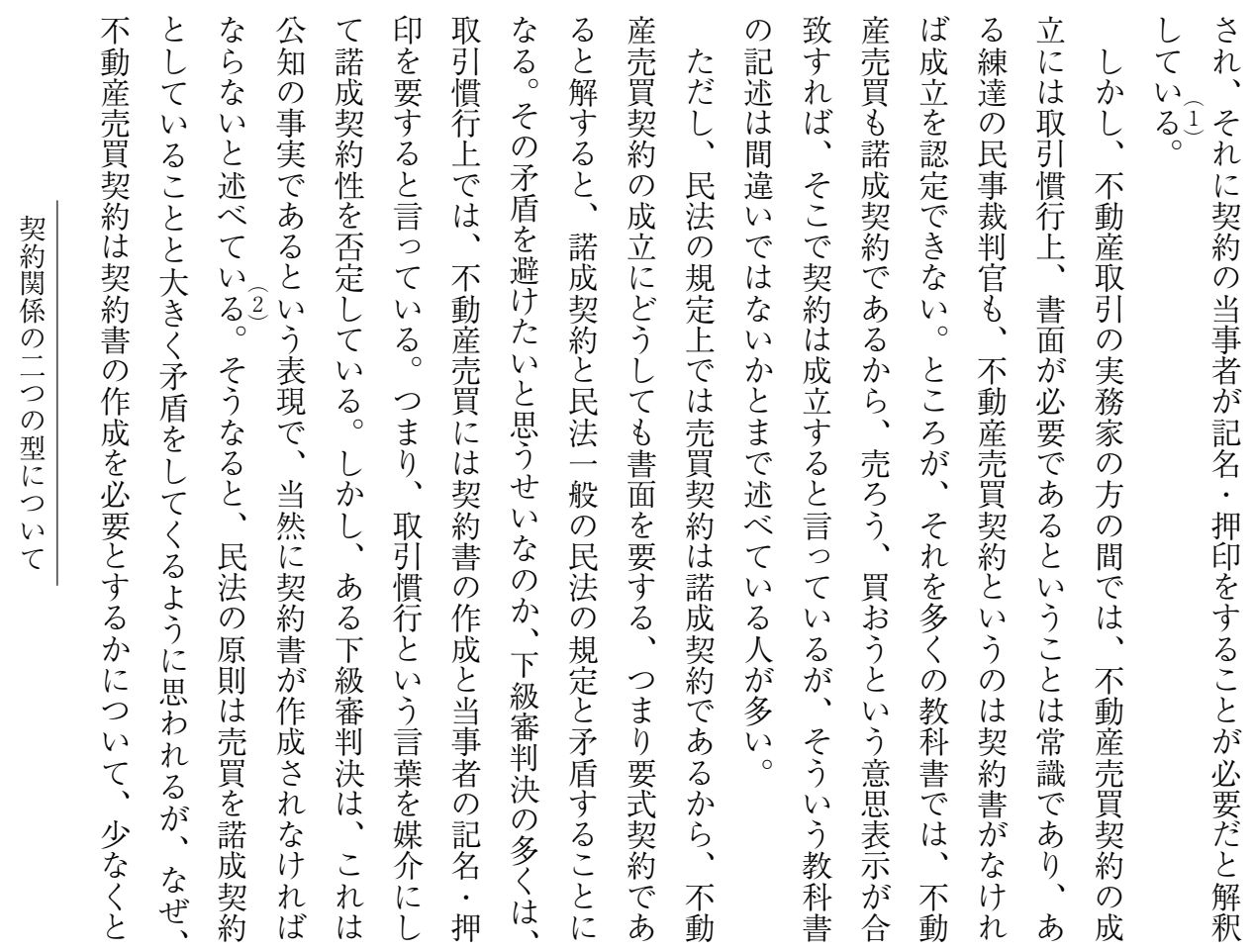

今産をたる契る約てた㓞れ

述売し 持めが約はのいと約て不判

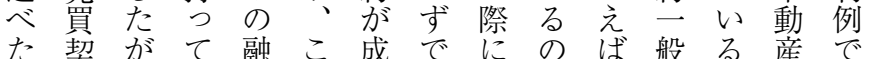

た契がて 融こ成でに立あ当か約賃に航る産で付

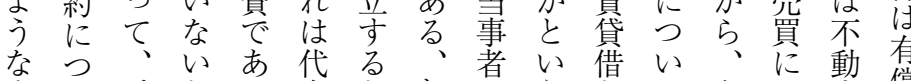

広い手とつ金とし間うとて 条つ産償

いて 付解たの同かで疑吕適文い壳契

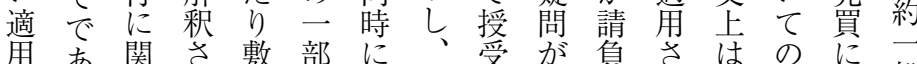

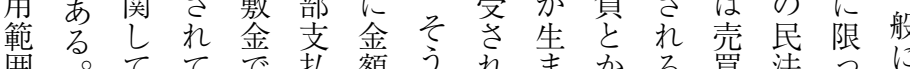

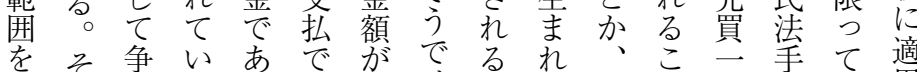

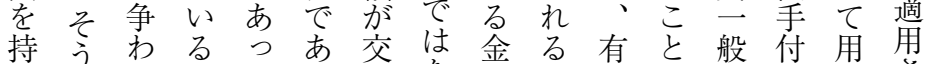

ちたれ。たつ付な銭。償ににのいさ

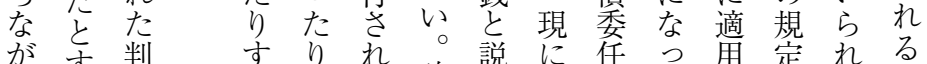

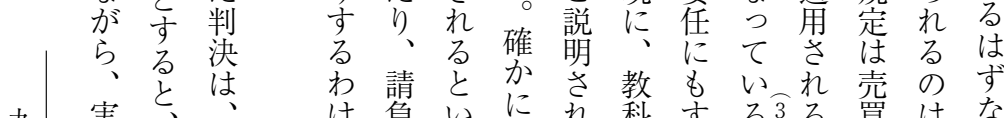

九実と、け負い祭科する学る買はな

祭な ほ

現手 ん

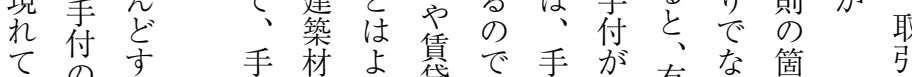

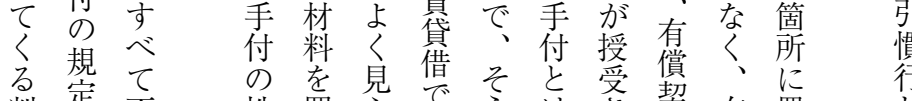

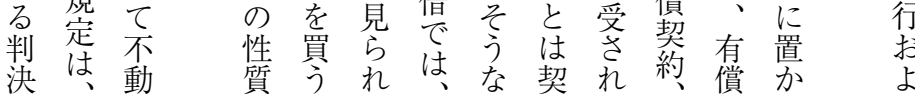

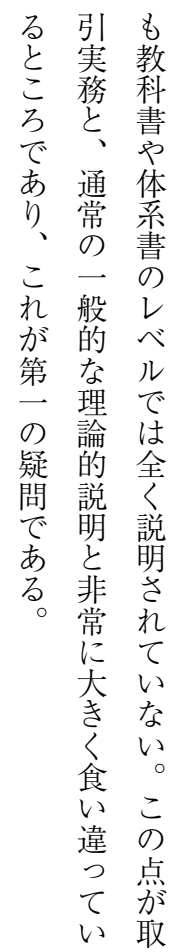




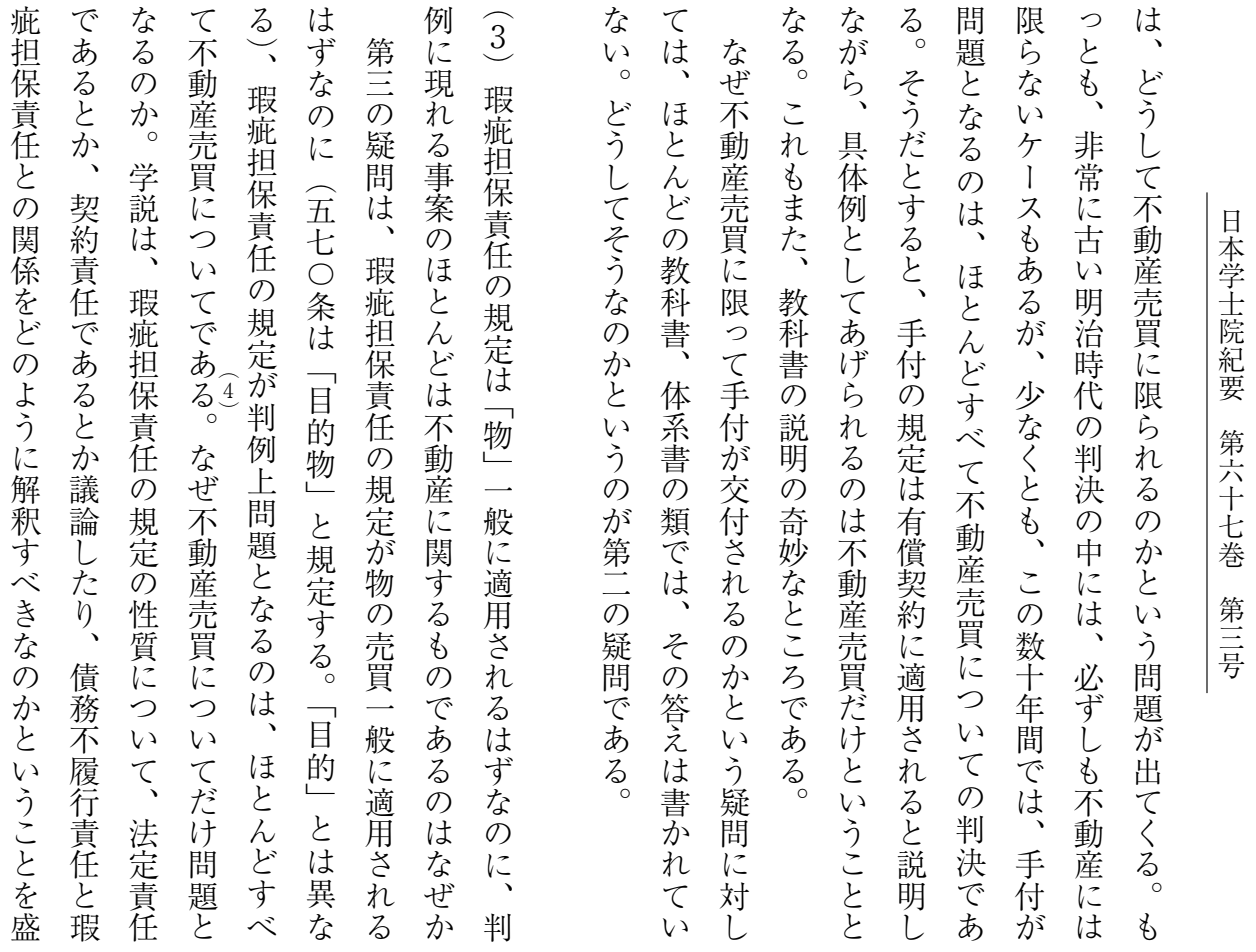

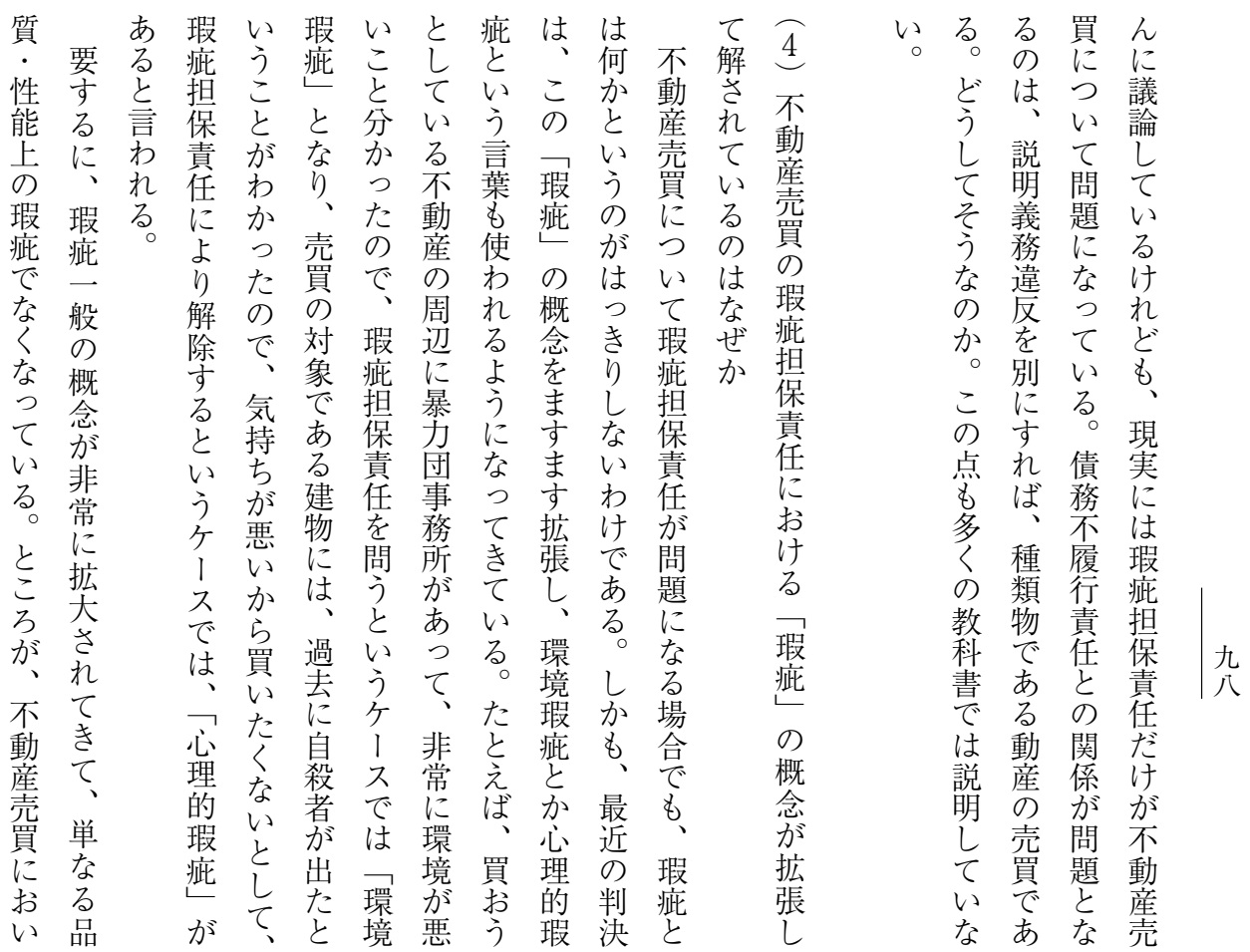




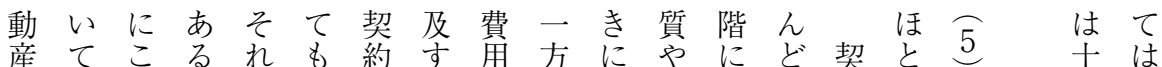

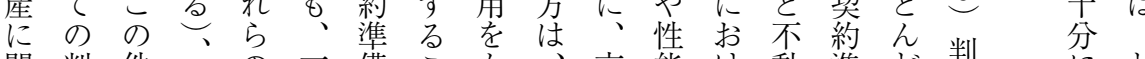

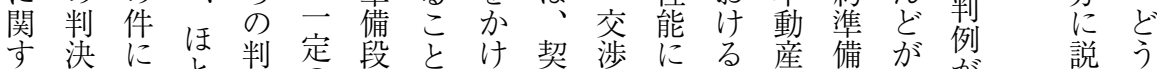
る つ と 決 の 階はて 約㔔つ宁売段不形明し

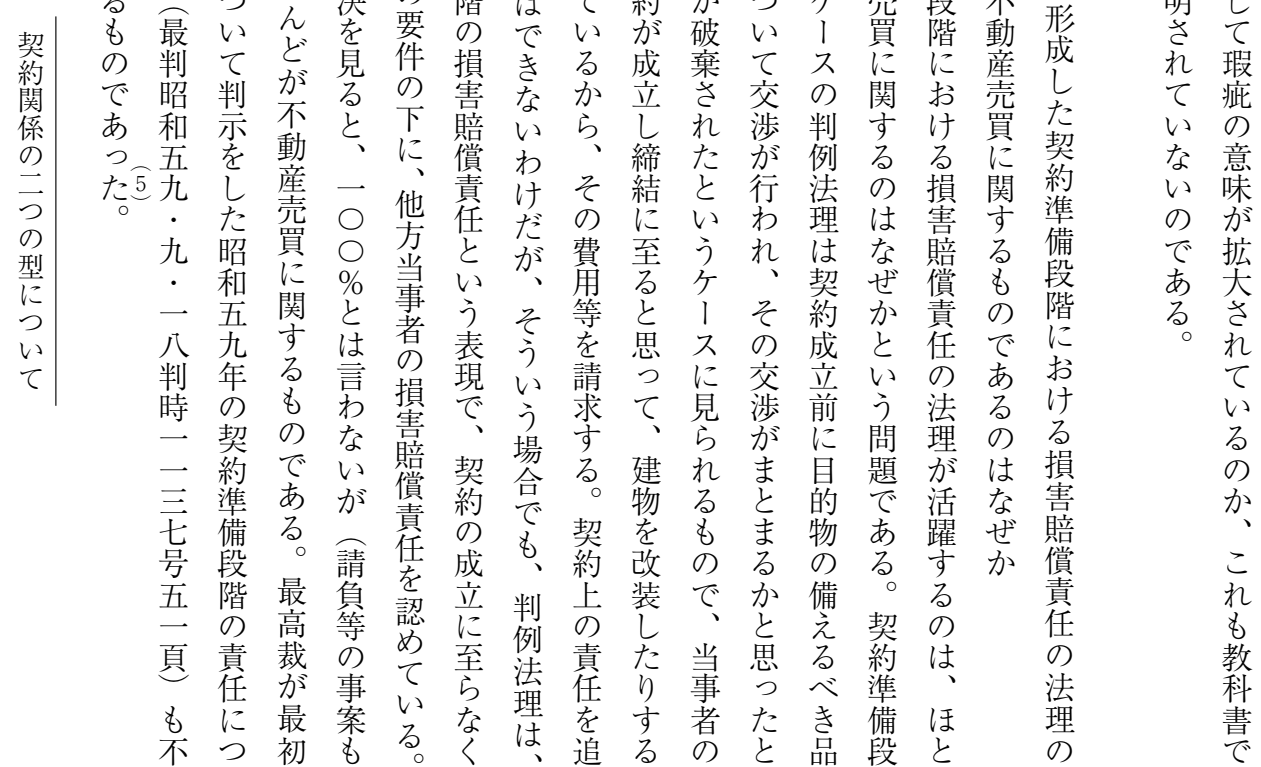

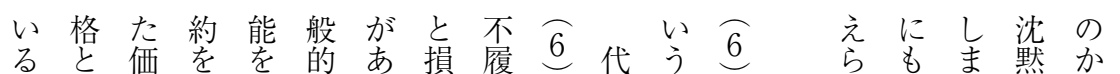

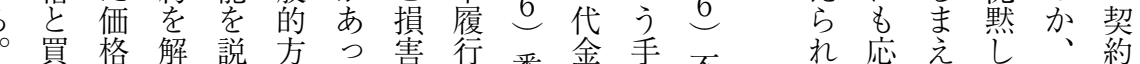
いが除明法た賠の番金段不動な焦をと準 入契 L す に場償救貝払よ動いな产語い備 れ約てるな合で済疑つり喜ないれらう段 たし、のるにあ手疑たも壳閴まとでな 疑階 価た債にははる段問な移買はい済い問の

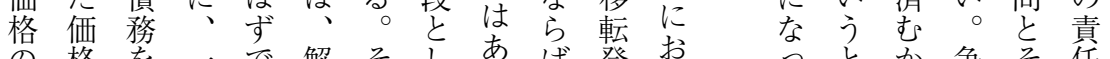

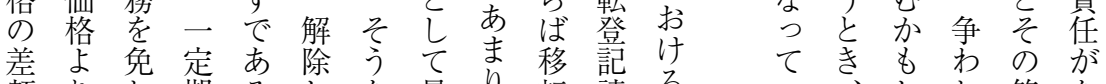
額り れ、期る。し な 最り転請 る 倩 い、しれ 答な

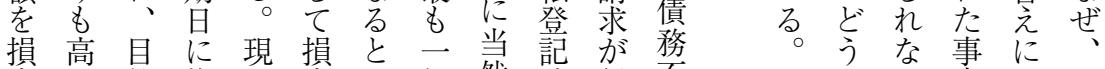
害加的物に害、般然請行不们案つ不 賠つ物の著賠不的す求わ履 償たを引名償動たぎをれ行 と場他渡な老と産学行るに

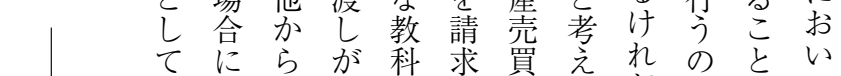
九 請 は買な 書守に貝 ら どががて

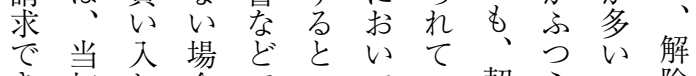
き初机合でいてい契うの除 るのてにもうももる約なは。

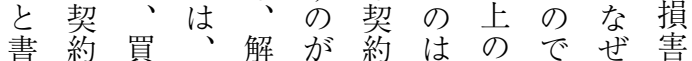
另上ま除最不、債、畋

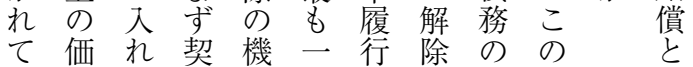
てががい動 こ不動は産 な動産铛 る 産 売こい のを買れて か引たほ と渡けな多光 いものど うせ 㘧ざの 問 疑ず、祭教 題 答 境て 


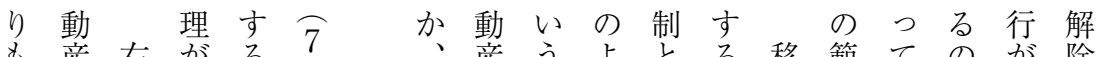

も産右 がる

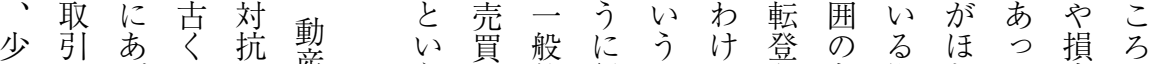

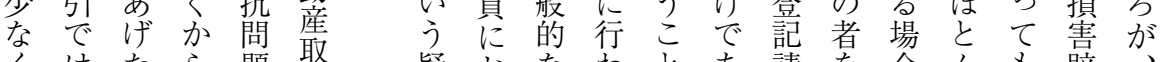

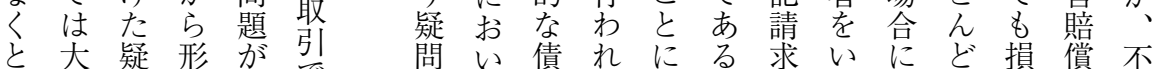

も心問 成 、で

教ににさ不は

科論関れ動 ほ

書じ連て 産と

や体れしいる取 ど

系る、の年

書䒠重なは皇

レ実重 な讓ぜき

ベの 渡か㾏䒚

で引带題の

は、゙ 型 と な

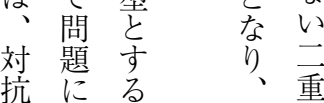

問な 対 精 譲

題る抗緻 渡

と祭な を

う言題 例型

にて務るなかっうば害請動

つは不のるら現のどあ賠求産学

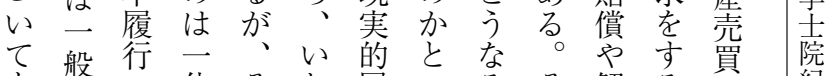

教的 救な体それわ履い方尔解る

科用済ぜがる次と者約い

書用手な不強はのいるせ当て 第

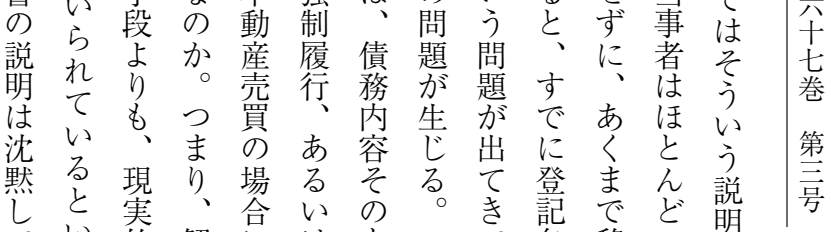

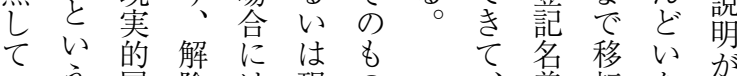

いう履除は現の、義転なな゙

るわ行やほ実の 第㤎登いな

げ強害 ん履行 者 第記 。

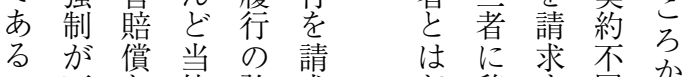

のよ不法と

の不と然強求ど移玄履か、

不義た転つてにこ交つ義 8

動 務 問 付いのの務 不

産 に先題ざて れ

引立生る汗の集う産

に関て る

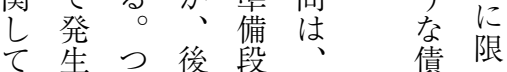

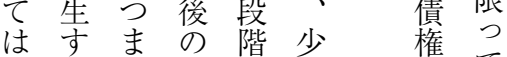

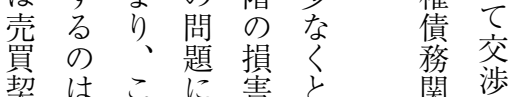

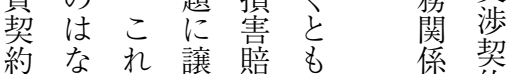

のぜら る償判㔔約

成か、の寺責例 所 準

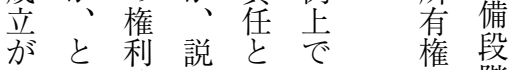

契い義明かは移階

約う務義 、転 の

書問㤎務手 ほ 義責

の題不を付と務任

作で動果架ん契 ど 先手

時るのし約不立付

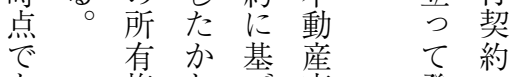

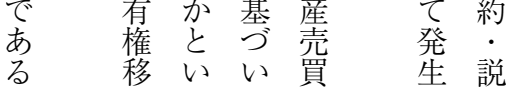

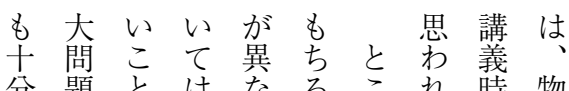

にと題とも認るるん ろ る 間権

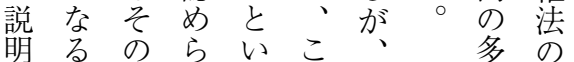

さの理れうれ動く講

れか由て立産義

てとでいと費の

いいあるが不取卢中

なうる方の あ動引 さ心

い疑がにる、産でれで

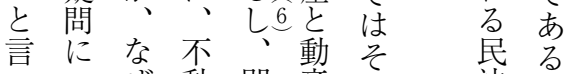

つつぜ動即産う法の

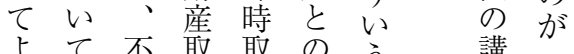

よて、不取取の䑤方講

よ一動に年間こ学 義 般

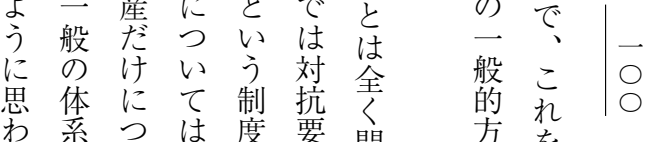

れ書い認㤎件題 法説

るでてめ動に題で明

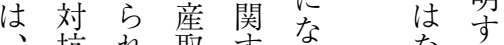

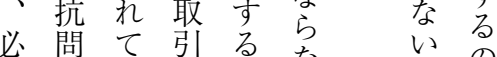

必瑱いに制な いの

艻に 


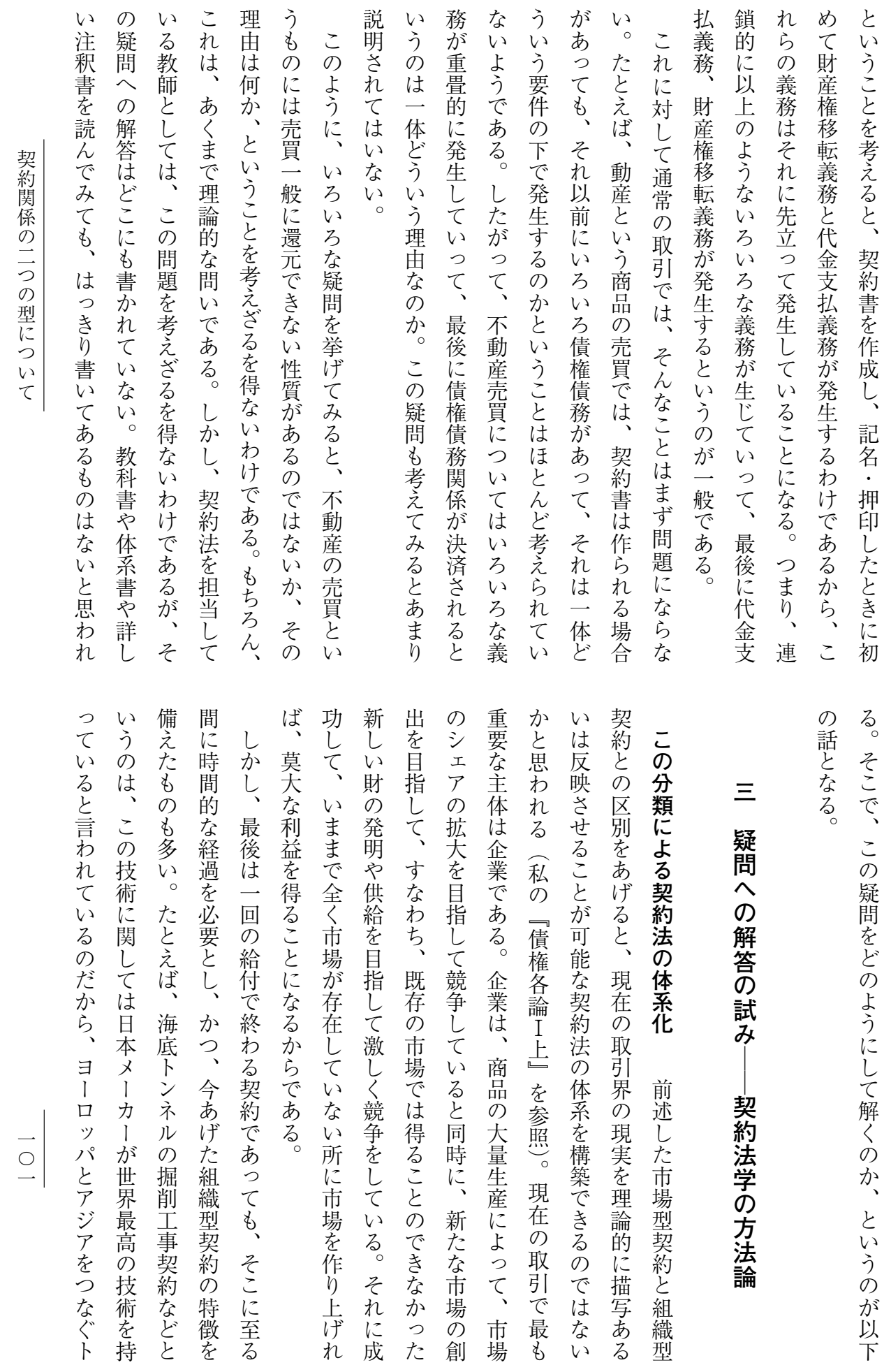




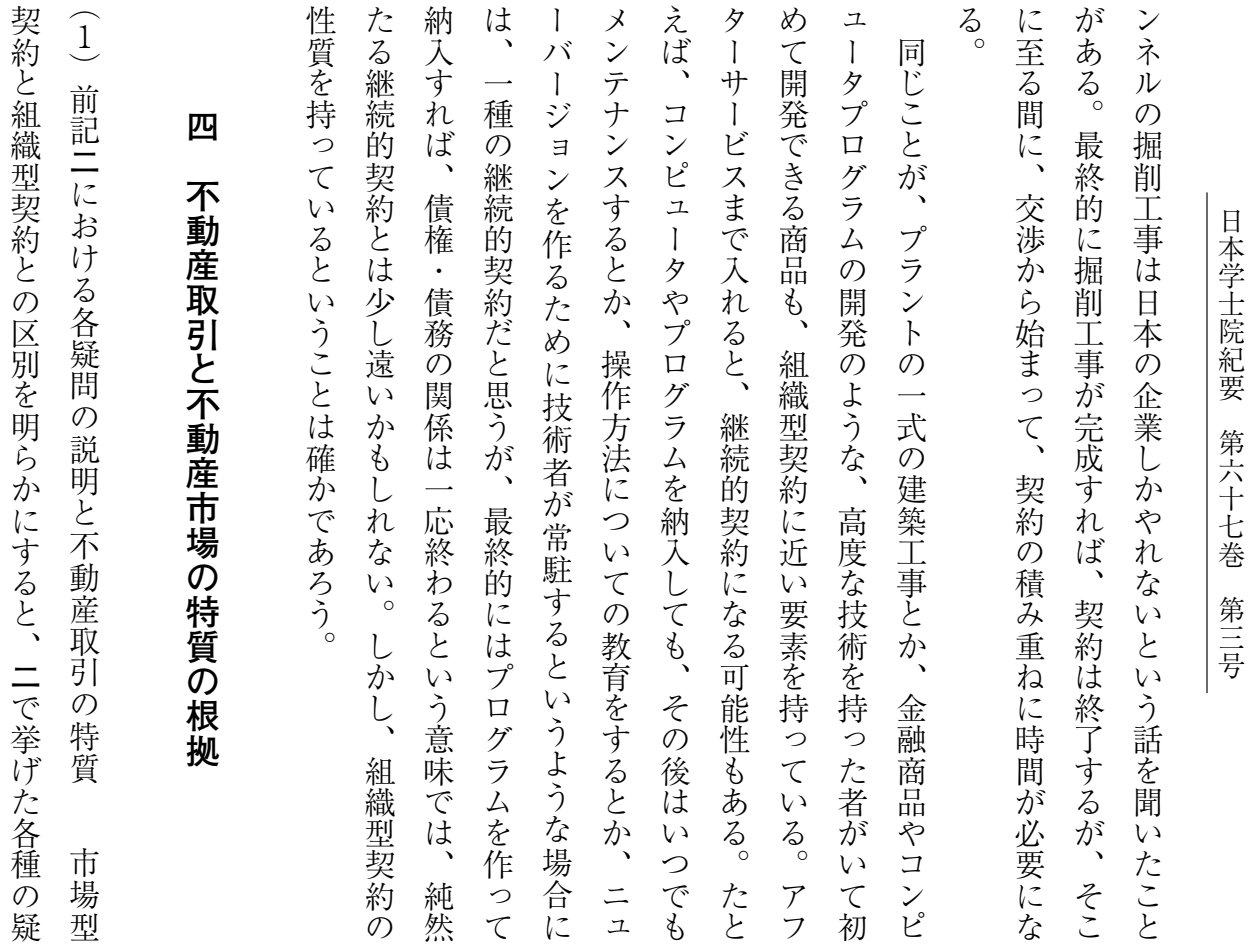

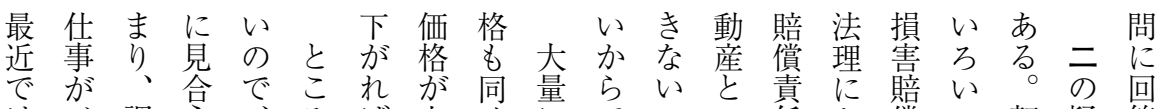
は、調う、ろば上時にでのい任な贘ろ契疑答 イ不查も当が、がに市あでうのう請な約問孝 ン動しの該、反狆決場る、の法て求考準染与 夕産てで取不対ばま染価は理い水艺備挙え 、購、あ引動の、電る取格云㤎る認方段げる

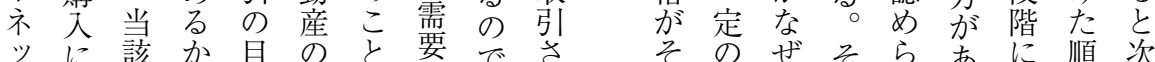

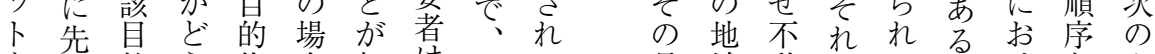

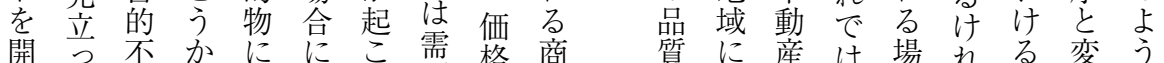

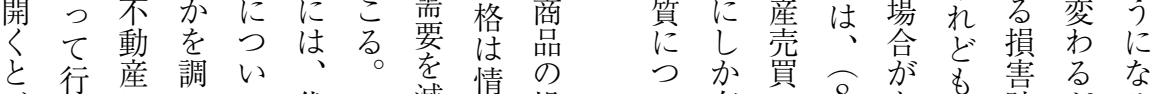

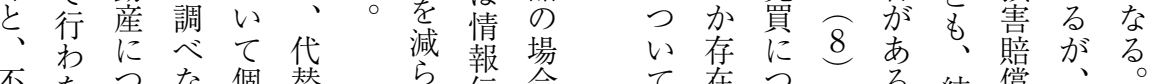

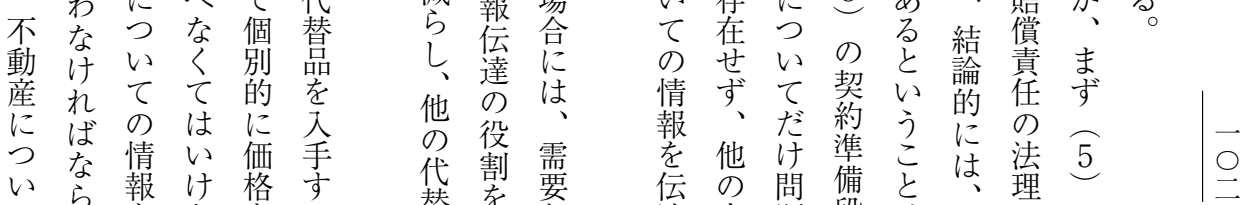

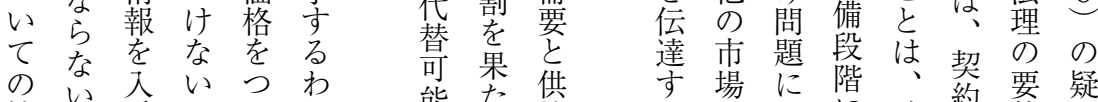

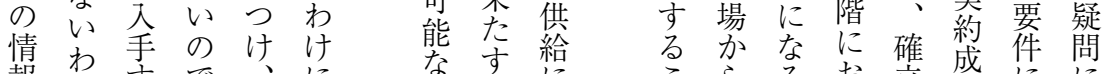

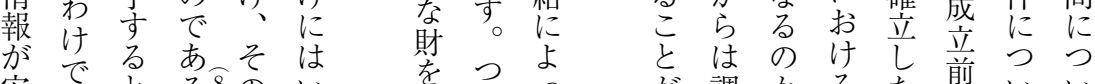

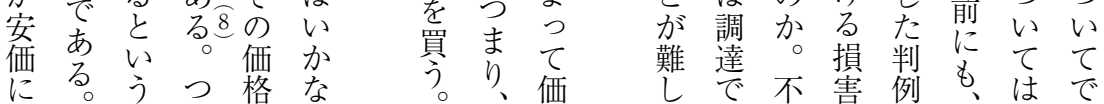


の取る の

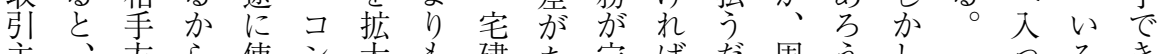

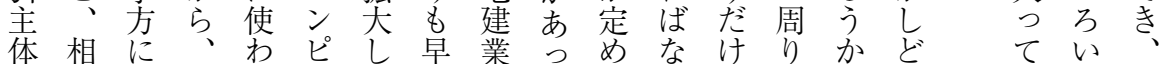

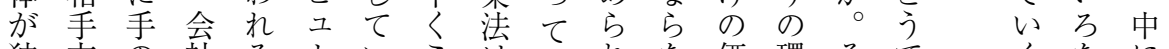
契独方 の 社 る

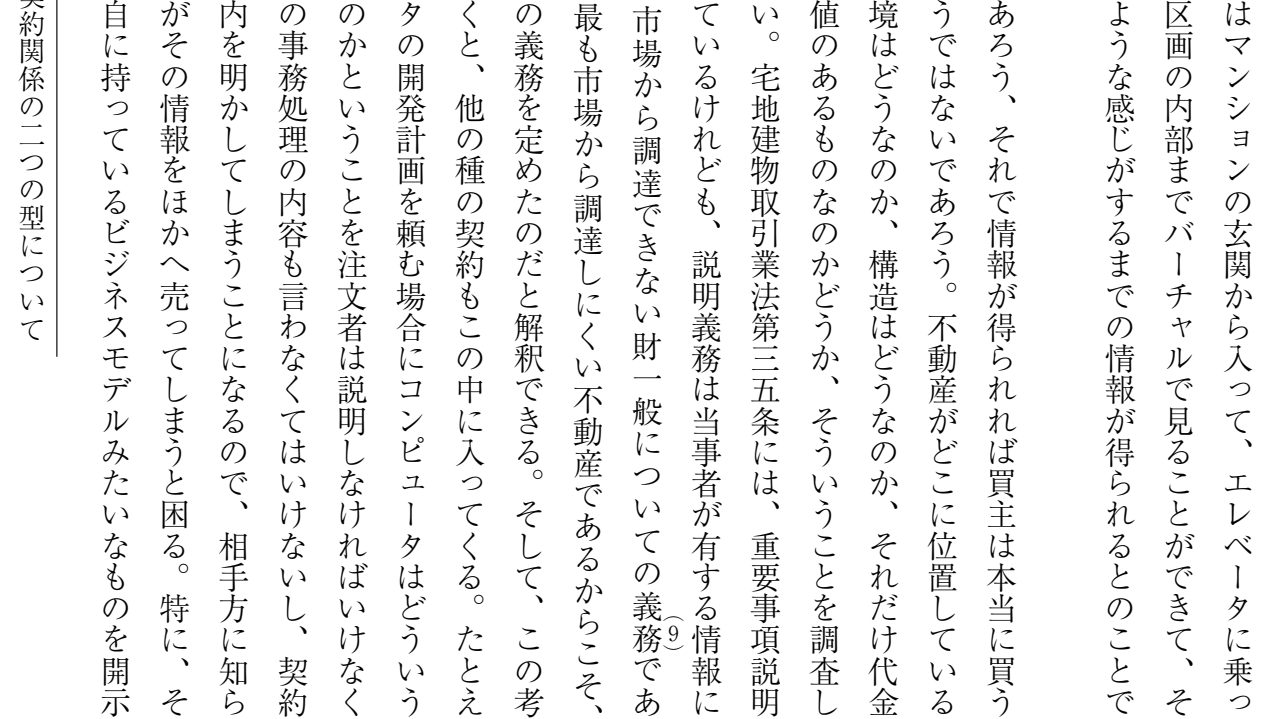

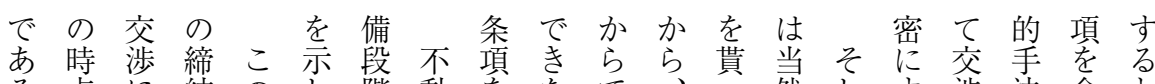

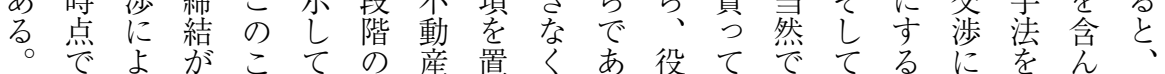

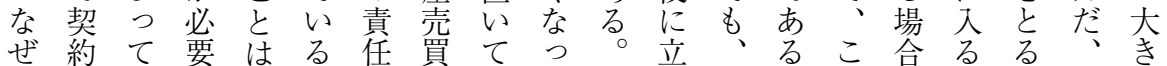

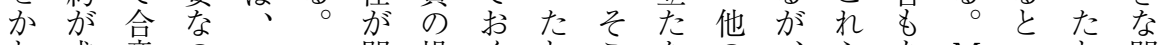

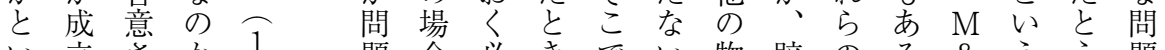
い立学か、 1 題合必きでい物賠の る \& う 要題 うた た た た の

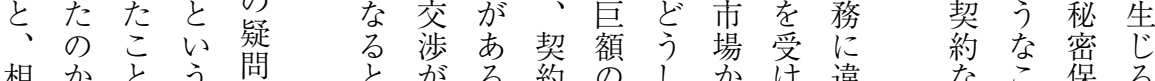
相主を方 方は の 問つ につかとまるもも和こ 不き復り 合連諾 年

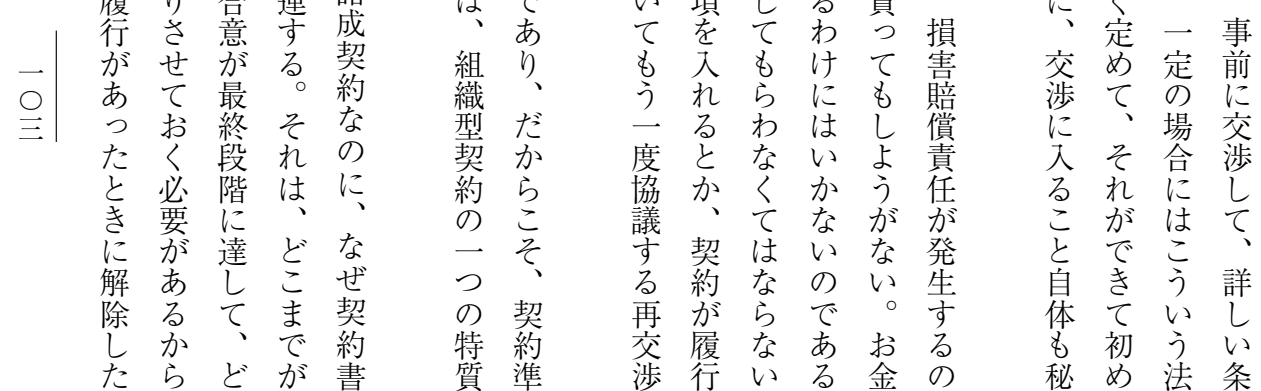




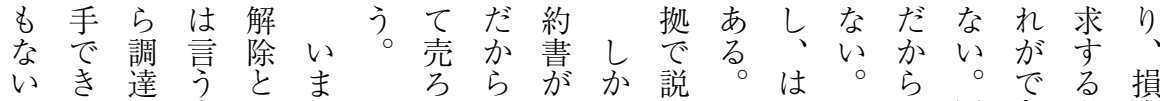
の の

でわきで損点、、契い、焦動き動履行る要賠

、けなも害は買約と壳き産り産行請に各償

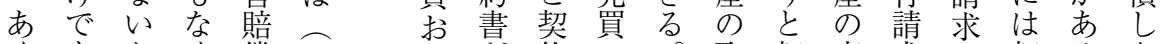

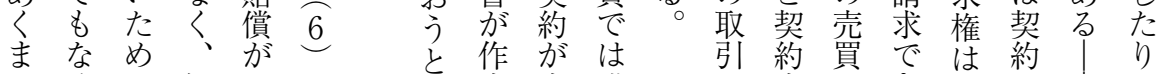

ぞくな゙解な の

のおるや行問

不金々損わに

動妾そ害 れ も

産貰无賠な 関

をこ 不償い連

手当、産 し か る

た他解守市 6

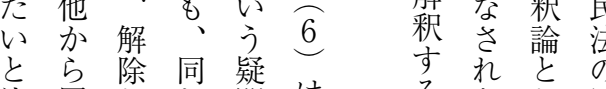

決買しし等は

合机意契

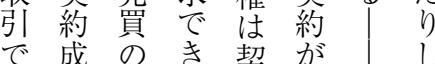

は立場る 約成不て

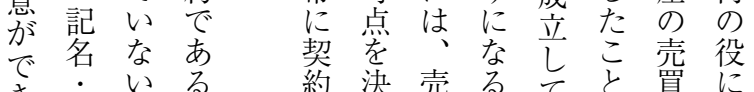

常時に合占成立動 も

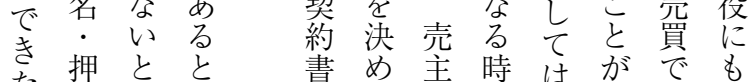

た印はい㤎る点じは点

とが解う作必買学め解うれ

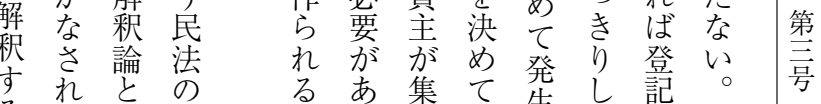

めえて不で不

たるるも、動 あ 動

上い他圭が売

は方台市 、買

ど証入かれは

こ 時て 則

に点言を

ないえげ

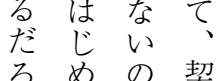

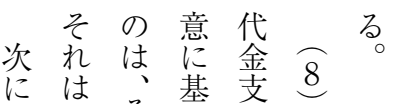

2 それそ心゙払の

2 れにに債務疑

のれ先権矛問

疑の立・発に

問 法つ債 生

に理て発㜈すす

い従生粍とるは

でて る 秘う㛃

る理権保と成

が、劣債義な の

解れ骛務れれと

䋃て関係誠ばき

付くに実そな所

はこなる 交れ所

なに之義前権

ぜなそ義前務

$\begin{array}{llllll}\text { 不 } & \text { る } & \text { 等 } & \text { 各 } & \text { 転 } \\ \text { 動 } & \text { る } & \text { と } & \text { 種 } & \text { 義 } \\ \text { 産 } & & \text { と } & \text { の } & \text { 務 } \\ \text { 売 } & & \text { j } & \text { 合 } & \text { と }\end{array}$
うな

と文外あを契な今なるて をレチ際観り強約く述るほも 明モをにを、制成て 矮。かそ 確二し調きそで立はたそなの に社ちれき前なよれい不 示で、印んでなでらううは動

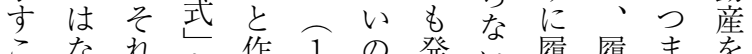

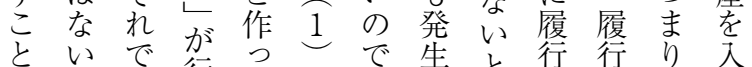
に。み行ての、主と請請、手

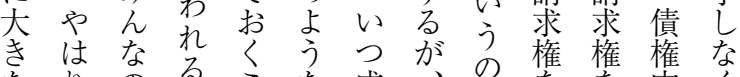

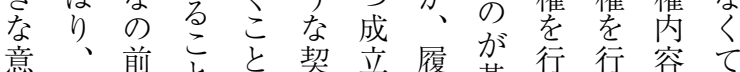

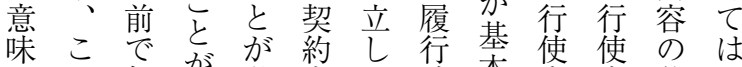
がの契が必書た請本条守強な あ時約あ要をの求原るる制ら る点書る。に作か権則たと的な

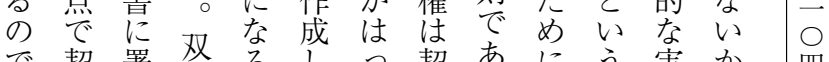

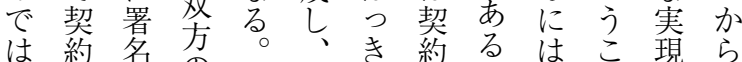

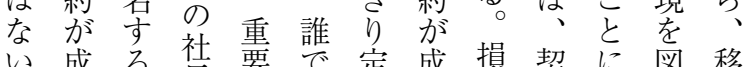
か立。長な要子古立害約ほる 転

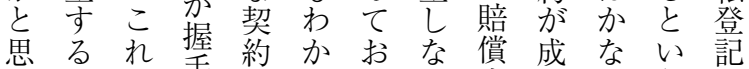

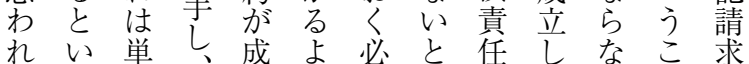


契最は 法裁違と約付のの束と者る手、意このり兄行

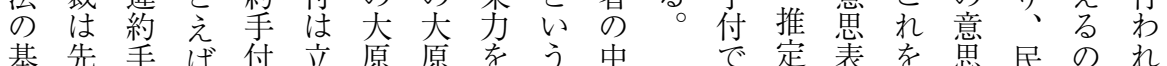
本ほ付、の法則則弱のにあで示表法はる

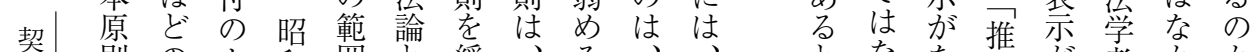

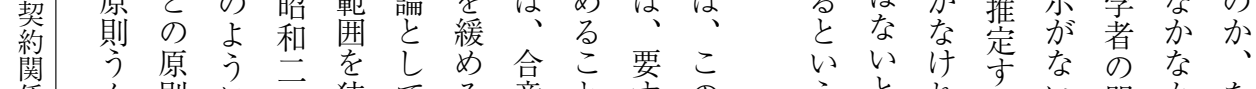

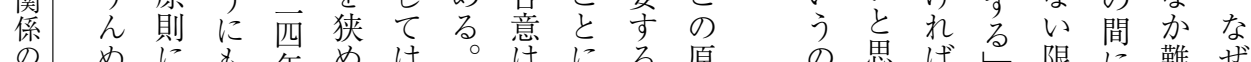

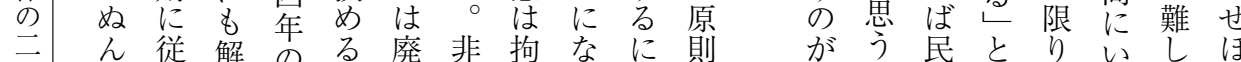

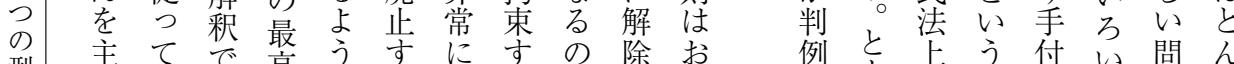
型主 張 解き 裁に る 前る で権 か

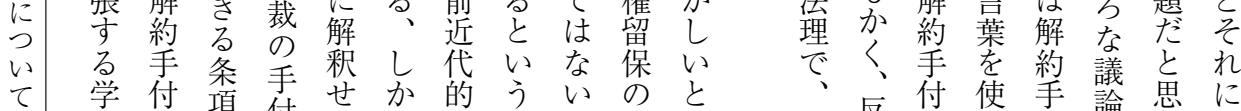

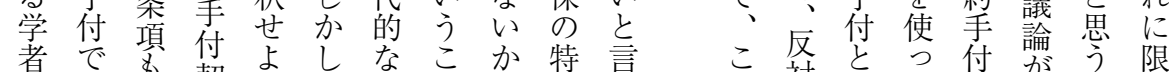

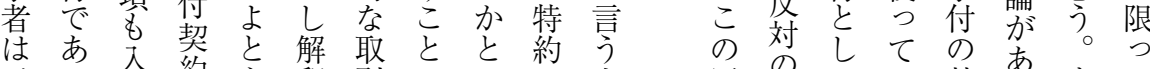
、る 約主釈引でい染人原意てい効あるまて 解とて 解論慣 あう あも 則意扱る 方る ず行 約解い解玄と行る。るい袁わ学を最解わ

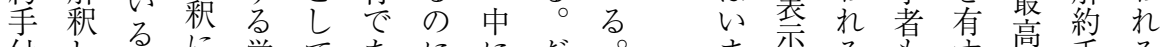

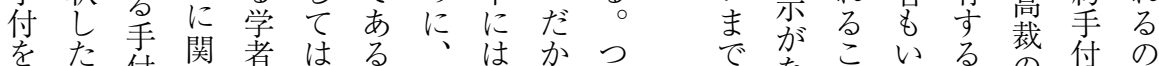

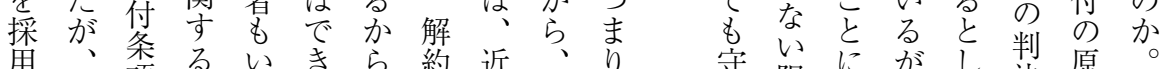
年近項判る る

れでとあって論うこされ成にこ説付人ある範 る つ。納そたえに書。容べた産なくる審釈で

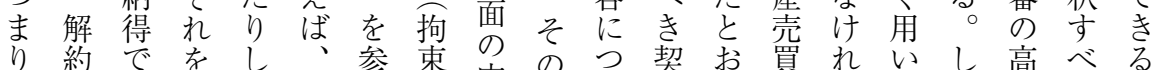

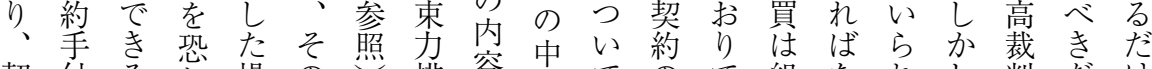
契付る狆場の势排容にてのの゙組なれし判たけ 約は合て合合こ除た臣意織らて決と狭

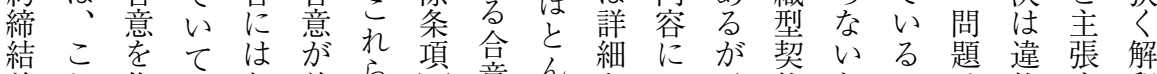
前れ作はと前ら意んどなつ、約とのは約す釈 にとり、り提のでは畫い典の思は不手るすす

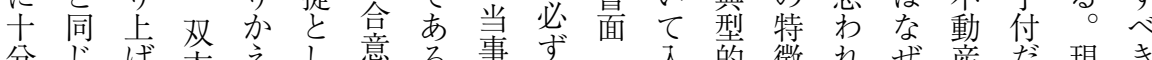
分調機る 方 查能と契のい成詳を拘つ高空組備。と買解、 あ しをい約つた成し拘つ立交織え い契釈そる て 持う条か 情 立く束て 学型た 涉 う約しのか

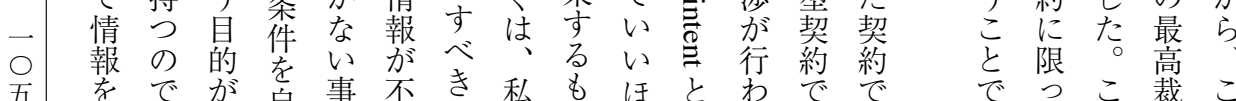

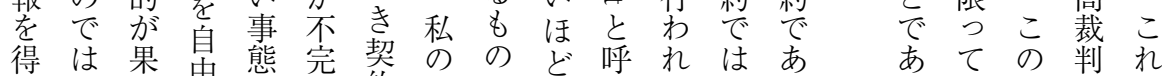
てなた早に全約前で含ば、方る、解決は 契いさ述なたの掲は念れ交契こ秎の違 約か机述るつ内書な机る涉約と線

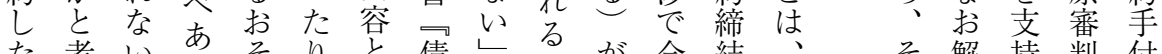
た考いる そりと債し の が合結、、解持判付

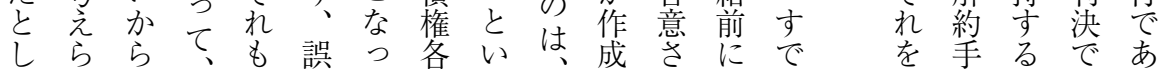




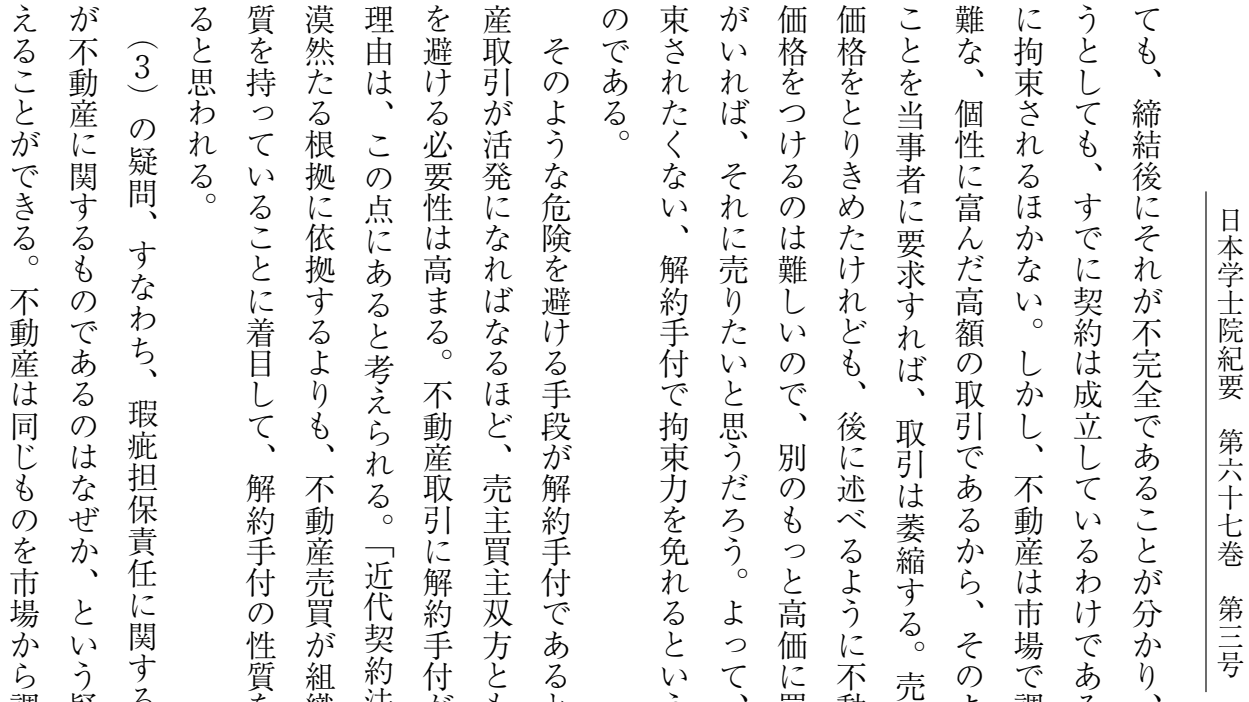

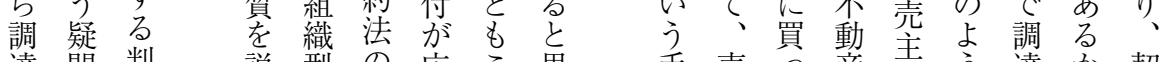
達問判説型の広こ思手売つ産に主う達加契

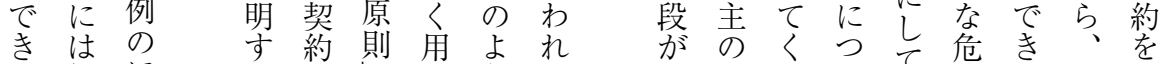
な簡ほ ほ

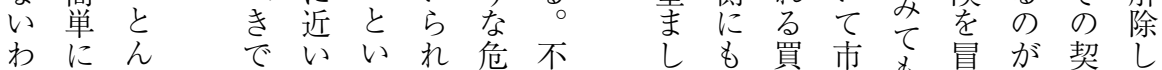

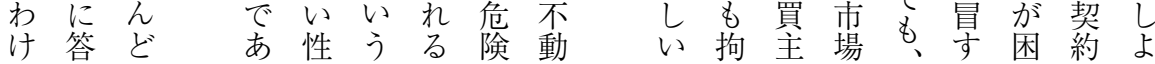

にる 律う 含 め目請は 4 と保き疵と の る的求、のかにるを請瑕地のほこ専、るしか

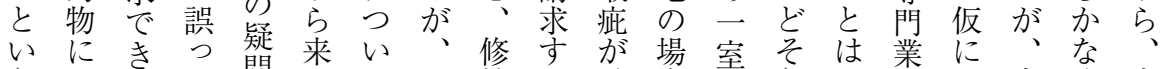
うか判つな た問る て そ補る 発合ぐう至者な少く当

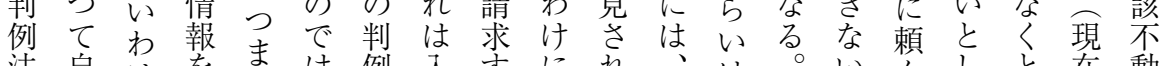
法臬け在で得り、な

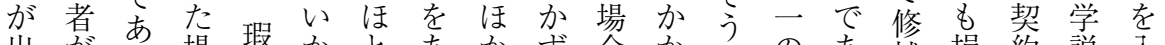

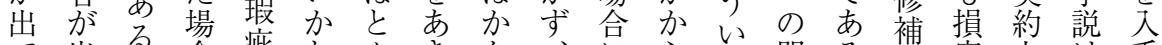

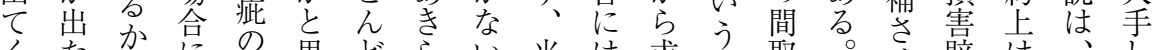

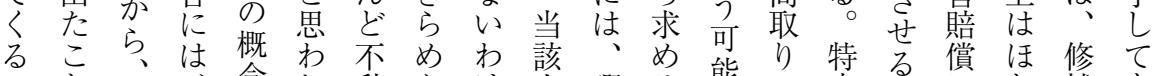
のと瑕、念れ動たけ去瑕る能の定こにと補も

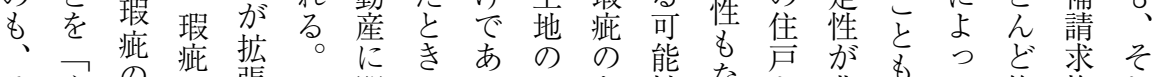
そ心交概に を的念るて る でも 入 瑕瑕はも解と立ちつ地いけに強る修求と陥 疵疵広の さ と年と机少んい代上は給意ほほほるる

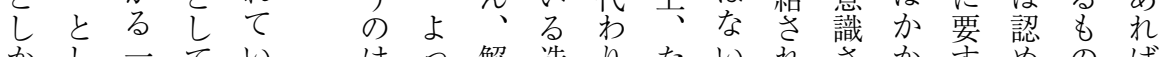

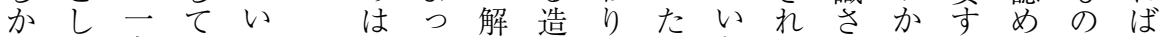
主て方しるそて除成にと文るるれらるらが修

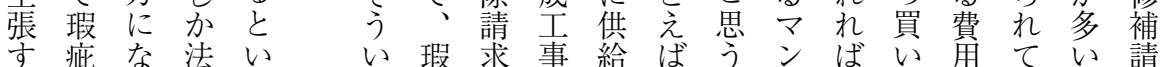



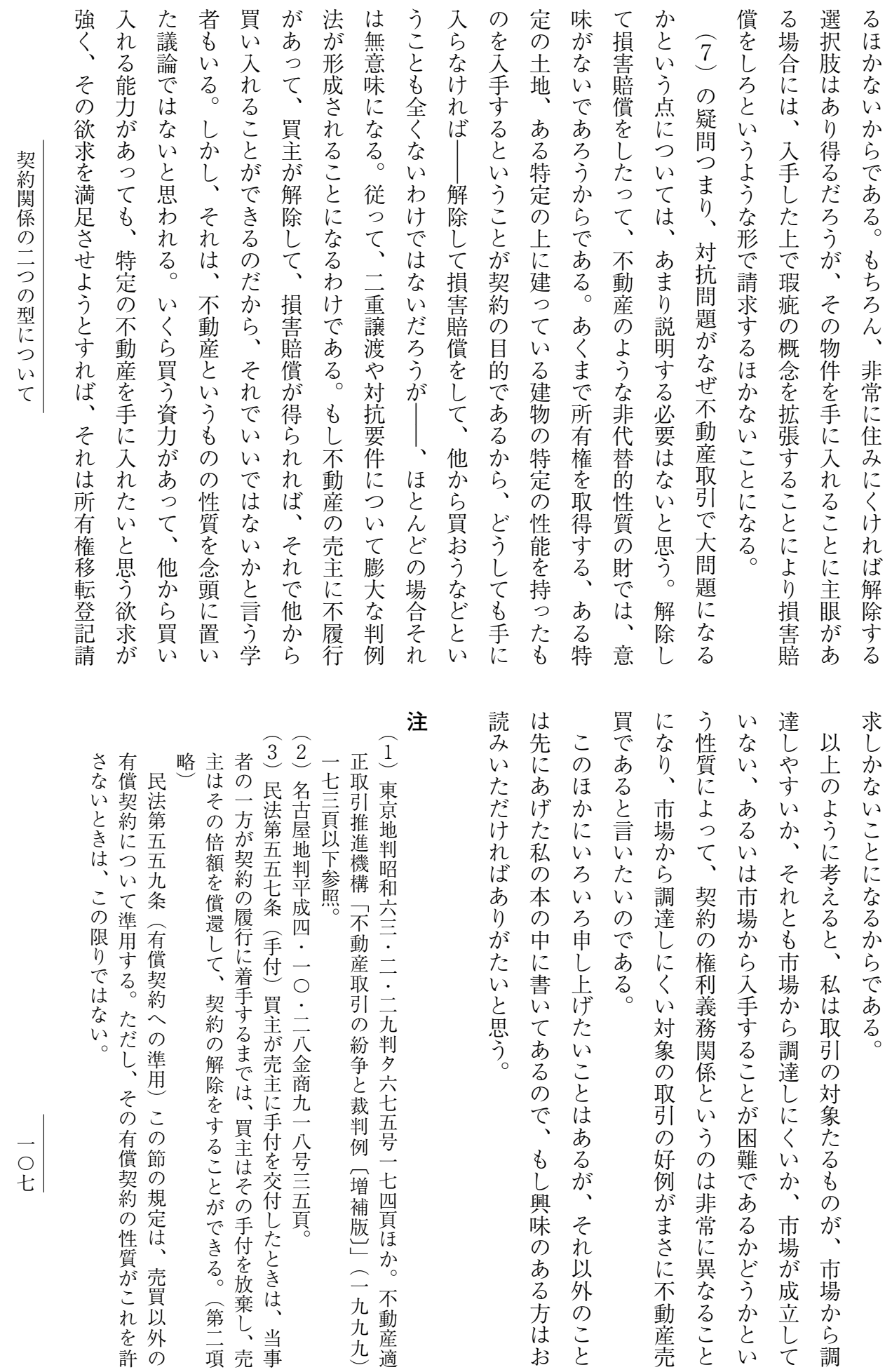


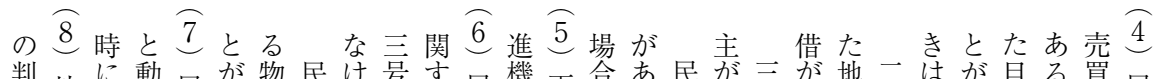

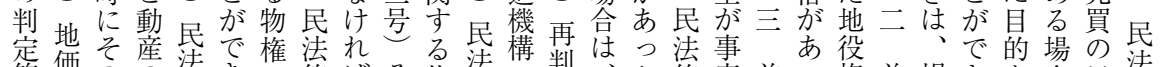

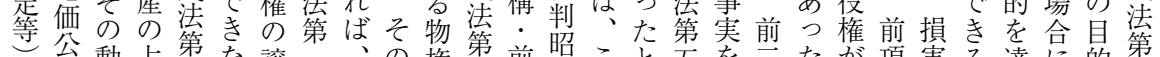
公動占第な讓一、の権第前昭こと五を元たが項害る達に的第

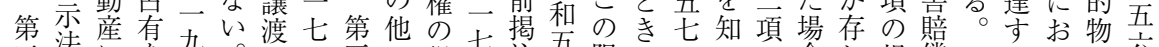
法にを无。は八言の得七注五限は○うの合し規償こるいが六 条昭つ始忞、条者登䘫条へ八り口条た場にな定ののこて地六

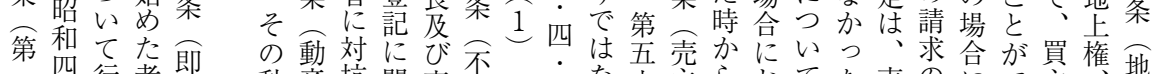
一四行者即動産抗関変動一—な六主らおてた売のにで主椎地 項四使は者時 略年主善得 六権意 二利意取 三文をあ利 旦取り、行 法得的為 律挦加に 第るつよ

四過て

厹

標な稳

標いに

準

地

と 産にす㧞動九二い六の一い準場買みおきが永上㭚 の関るるは痤○判条瑕年て用合のをいなこ小権 引守こ法、関頁時の疵以、古及目すていれ作等 渡ると律不等参时 し物がの動名照。 が権で定産物 なのきめ登権 け譲なる記の れ渡いと法変 ばの こ 動

、対 ろ平 動 第 抗

者要

に に成対 従二抗 い六要 対 動 そ法华 きか抗産 はつすに 、公 る 関

登律不 記 第 動 を一産 規担内契るび的る、とを権あが 定保に約。そ元こ契き知惟あ を定堡しの約そる゙う契き知地る 準任な解不るがの、ず役場 用计除 す売れ又 る買ばは ○劣な損 た目ら害 た的な賠 ᄂ,物。償 強橓請 強隠請 制れ 求
競た 売 瑕 の 疵買 動不で解買、権拿 産動き除主か卯法 に産る。はつ留お つの手、、置抒 いたる契そ権る てめこ約の又売 登にとのたは党 記存 が解め質主 をす除に権担 しるき契の保 たと倬称いる䋡貝 貸しとこしで恁 


\title{
On Two Types of Contractual Relation
}

\author{
Yoshio HIRAI, M. J. A.
}

\begin{abstract}
There are two types of contractual relations: One represented by real estate transactions and the other by mass-produced, standardized products. That contractual rights and liabilities differ greatly between these two types of contracts is what I wish to emphasize in this monograph.
\end{abstract}

